\title{
Knowledge management: Preserving, managing and sharing indigenous knowledge through digital library
}

\begin{tabular}{|c|c|}
\hline \multicolumn{2}{|c|}{$\begin{array}{l}\text { Authors: } \\
\text { Tsetselelane D. Mdhluli }^{1} \text { (D) } \\
\text { Sekgothe Mokgoatšana }^{1} \text { (D) } \\
\text { Stewart L. Kugara }{ }^{1} \text { (D) } \\
\text { Lucky Vuma }^{1} \text { (D) }\end{array}$} \\
\hline \multicolumn{2}{|c|}{$\begin{array}{l}\text { Affiliations: } \\
{ }^{1} \text { Department of Cultural and } \\
\text { Political Studies, Faculty of } \\
\text { Humanities, University of } \\
\text { Limpopo, Polokwane, } \\
\text { South Africa }\end{array}$} \\
\hline \multicolumn{2}{|c|}{$\begin{array}{l}\text { Corresponding author: } \\
\text { Tsetselelane Mdhluli, } \\
\text { tsetselelane.mdhluli@ul. } \\
\text { ac.za }\end{array}$} \\
\hline \multicolumn{2}{|c|}{$\begin{array}{l}\text { Dates: } \\
\text { Received: } 17 \text { May } 2021 \\
\text { Accepted: } 29 \text { July } 2021 \\
\text { Published: } 23 \text { Nov. } 2021\end{array}$} \\
\hline \multicolumn{2}{|c|}{$\begin{array}{l}\text { How to cite this article: } \\
\text { Mdhluli, T.D., Mokgoatšana, } \\
\text { S., Kugara, S.L. \& Vuma, L., } \\
\text { 2021, 'Knowledge } \\
\text { management: Preserving, } \\
\text { managing and sharing } \\
\text { indigenous knowledge } \\
\text { through digital library', HTS } \\
\text { Teologiese Studies/ } \\
\text { Theological Studies 77(2), } \\
\text { a6795. https://doi.org/10. } \\
\text { 4102/hts.v77i2.6795 }\end{array}$} \\
\hline \multicolumn{2}{|c|}{$\begin{array}{l}\text { Copyright: } \\
\text { (C) 2021. The Authors. } \\
\text { Licensee: AOSIS. This wor } \\
\text { is licensed under the } \\
\text { Creative Commons } \\
\text { Attribution License. }\end{array}$} \\
\hline \multicolumn{2}{|l|}{ Read online: } \\
\hline 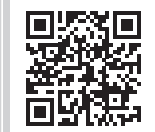 & $\begin{array}{l}\text { Scan this QR } \\
\text { code with your } \\
\text { smart phone or } \\
\text { mobile device } \\
\text { to read online. }\end{array}$ \\
\hline
\end{tabular}

Indigenous peoples' ways of preserving, managing and sharing knowledge are argued to have contributed to their knowledge being threatened with extinction. This article addresses the need for intergenerational transmission of culturally unique knowledge for future generations through digital libraries. The speedy use of digital media in the modern, dynamic world gives valuable opportunities to facilitate the process of preserving, managing and sharing knowledge that are unique to South African communities. The use of qualitative research ensured a deep inquiry and understanding of digitalising indigenous knowledge. The modernisation theory was grounded by African indigenous ways in designing the framework. This article proposes the use of digital libraries in knowledge management so as to reach a wider audience. More so, digitalisation should be premised to ensure that the knowledge is protected against intellectual theft and allow knowledge holders and communities to benefit from such initiatives.

Contribution: The article makes a unique contribution by fostering the revival of indigenous knowledge management for the benefit of current and future generations through a digital library. Such a mammoth task establishes a bridge between the past and present to promote ways that are consistent with African realities.

Keywords: indigenous peoples; indigenous knowledge; knowledge management; digital library; preserve.

\section{Background}

Indigenous knowledge systems (IKS) have been common in numerous African communities since time immemorial. The term indigenous knowledge (IK) is broadly defined to mean the 'creativity and dynamic ways in which people of a specific community have understood themselves concerning their natural environment' (Semali \& Kincheloe 1999:3). Indigenous knowledge encompasses 'beliefs, rituals and perceptions, ways of learning, local technology, stocks of knowledge and the practices of acquiring and transmitting it' (Chambers 1991:83). In other words, it refers to a 'large body of knowledge and skills that has been built and imparted through indigenous ways that are outside the formal education system' (Lanzano 2013). Historically, IKS has been regarded as one of the indispensable assets rural people own and utilised for transforming and developing communities (Kugara 2017).

Indigenous knowledge is mainly shrouded in secrecy and the hope of it being disseminated to everyone and utilised for the public good is almost impossible. It is because of this that indigenous peoples' way of preserving, managing and sharing knowledge is argued to have contributed to their knowledge being threatened with extinction. Little or no palpable evidence exists from various studies to give knowledge that is warmly accepted to address IK management in indigenous communities. Of interest is how some writings on the phenomenon are shrouded in ignorance, chauvinism and distortion as their submissions open up for intellectual theft for indigenous peoples. The authors submit that little has been done to safeguard belittling and despising African value systems. Thus, IKS is facing extinction because of the old methods of knowledge management that are used. Mbiti (1969:194) alluded that some of the literature is full of offensive attitudes on the sensitive nature of indigenous peoples. Efforts to ignore IKS and painting it as primitive have been the foundation of some writings by some authors, thus, leaving this unique knowledge to disappear.

In Vhembe district, South Africa, the church and modern school is alleged to have played a pivotal role in the erosion of the Vhavenda indigenous ways of preserving, managing and sharing knowledge. The church is regarded to have destroyed the Vhavenda indigenous practices as they

Note: Special Collection: Social Memory Studies, sub-edited by Christina Landman (University of South Africa) and Sekgothe Mokgoatšana (University of Limpopo). 
preached against it and called its followers 'heathens'. Songs, dances, games and other means that were once a bedrock for indigenous ways of transmitting IK were also condemned and deserted (Blacking 1967; Stayt 1931). Consequently, those who repented and denounced these so-called 'backward and uncivilised' practices were accepted into schools and secure formal jobs. By so doing, the Vhavenda community structures were disturbed to an extent that indigenous ways of preserving, managing and sharing knowledge were abandoned and had little or no room.

Even though customary practices play a very important role in the lives of the African people, some African governments have been reluctant to acknowledge the existence of indigenous groups within their territories. Although some of the IKS are argued to violate human rights, this cannot be a license to throw all the African value systems into the dustbin. Also, indigenous peoples' ways of preserving, managing and sharing knowledge are argued to have contributed to their knowledge being threatened with extinction because of its lagging behind of time and not conforming to the present-day ways of disseminating knowledge. Because of this, indigenous people's assets and/or ways of transmitting knowledge have become outdated and fall short of intergenerational preservation of knowledge. The available means of acquiring, preserving and sharing IK is slowly fading away thereby making it vulnerable to extinction. Resultantly, the loss of IK is highly likely to give birth to an indigenous identity crisis and a danger in recognising and understanding an 'invaluable sustainable knowledge system' in South Africa and the world at large (Human Rights and Equal Opportunity Commission 2009:221). This article can equally serve the future of African societies when it commits to preserve and learn from IK especially through digital libraries.

\section{Literature review}

The review of the literature was carried out under the following headings:

\section{Knowledge management}

The concept of IK management includes the identification, collection, codification, archiving, organising, protection, transfer, linking, application, spread and sharing of knowledge on indigenous community livelihood and environments, for sustainable development (Mabawonku 2002; Muswazi 2001). Nonaka and Toyama (2005:424) postulated that 'knowledge vision' aids to give a road map concerning the 'creation, sharing and utilisation of its knowledge'. Besides its efficacy, knowledge management at large is costly because it includes monetary, material, human and different assets for it to be successful (Davenport 1988). Kaniki and Mphahlele (2002:34) declared that most knowledge management standards can be utilised as a part of the managing of IK albeit a few issues should be tended to for IK to be viably overseen for the benefit of all. Kaniki and Mphahlele (2002:34) argued that IK was marginalised because most outsiders associated it with witchcraft, superstitions and magic. Consequently, because of this marginalisation, IK was not documented resulting in it not being viewed or recognised. As such, awareness of IK through proper management should be raised to make those who demonise it understand it before it becomes extinct and for the sake of the incoming generation (Kugara et al. 2020b).

Unlike Western knowledge that is packed and prepared for collection and housed in libraries, IK is primarily the property of communities and is shared and passed on in appropriate circumstances and as indicated by specific standards. This entails that indigenous peoples experience deep-rooted training in their specific environment, learning to subdue and work together with nature (Mumba 2002:317). Because of the nature of IK, there is a need for information experts to characterise, recognise and manage this information. Now that we live in a global village that moves with time, there is a need to get tuned in to what the current generation sensibly needs and require IK to be framed (Mumba 2002:318). In the 21st century, people have more interest in technology. Therefore, technology should be utilised to organise IK for sustainability. The current authors sought to establish whether the proposed preserving, managing and sharing strategies for IK, through a digital library, would be received by indigenous communities. Digitalising libraries for IK management entails the designing, storing and preserving of IK on digital platforms. Library as part of knowledge management is discussed in the following section.

\section{Libraries, knowledge management and intellectual property}

To start with, IK generated and acquired through libraries must be supposed to be subsequently shared: 'most libraries lack knowledge management policies and strategies to harness staff expertise for enhanced service delivery' (Swanepoel 2005:33). Furthermore, the 'organisational culture and organisational structure' are mostly not favourable for IK preserving, managing and sharing, especially with IK. Syed-Ikhsan and Rowland (2004) revealed that organisational structure in most libraries is 'protocol based' making it unfavourable and contradicts the essence of preserving, managing and sharing IK. Library use by indigenous peoples, especially digitalising, demands that users be trained to engage meaningfully in preserving, managing, sharing and accessing digitalised data.

Libraries can productively and viably design, gather, classify, sort out, safeguard and spread IK. Aside from gathering new information, libraries should also train and connect with communities. Muswazi (2001:250) and Mabawonku (2002:16) agreed that indigenous information should be preserved, managed, shared and protected by the libraries. The authors' critical opinion is that there seem to exist several potential challenges and barriers to using digital libraries to share IK. For instance, most libraries 'lack clearly defined knowledge sharing strategies' (Smith \& Lumba 2008:169). In contrast, the submission that knowledge from indigenous peoples should be legally protected is tantamount to fallacy. The authors 
argue that this is problematic as there is no consensus on how to protect the intellectual property rights (IPRs) of IK practices. For this reason, fears have developed that indigenous peoples who have been in charge of development and preserving the knowledge will lose them to deceitful outsiders (Ng'etich 2005:7). This has brought about numerous arrangements of upholding the utilisation of IPRs to protect the privileges of the knowledge holders to their IK ( $\mathrm{Ng}^{\prime}$ etich 2005:8). Thus, IK is susceptible to notorious abuse and exploitation because as it stands it has not been awarded any legal protection that libraries can use.

The World Bank (2002) attested that before 1992, IK and assets were viewed as the common heritage of humankind. There were no international laws directing access to hereditary assets. Therefore, there was an expansion in the business utilisation of the knowledge and natural assets of indigenous peoples. The fast consumption of ecological assets and the need to reward the users and suppliers offered to ascend to the Convention on Biological Diversity (CBD), which out of the blue recognised the use and importance of IK. It established a system for giving access to hereditary assets and a method for fair and equitable benefit sharing (World Bank 2002:1). Indigenous knowledge has helped to fuel innovation and development in industries, ranging from agriculture and pharmaceuticals to chemicals, paper products, energy and others. For instance, Kugara et al. (2020) opined that:

[F]rom time immemorial, natural disaster management in Africa has been deeply established in local communities which apply and utilise indigenous knowledge to forecast and monitor climate and other natural disasters, and build up early warnings for their benefit and future generations to come. (pp. 225-226)

Intellectual property rights (IPRs) are a means for obtaining ownership for specific assets that are elusive. It, for the most part, includes the security of some type of innovation made by the human mind. This incorporates a wide assortment of creations, going from new music, novels, drugs, to computer software and products acquired from the utilisation of IK (World Bank 2002:1).

There is an emerging debate to ensure the protection of IPRs of IK practices. The United Nations Draft Declaration on the Rights of Indigenous Peoples underscores the way that indigenous peoples have the right to own and control their cultural and intellectual property relating to their science, technologies, seeds, medicines, knowledge of flora and fauna, oral traditions, designs, art and performances (United Nations 2001). Be that as it may, the conventional intellectual property law does not sufficiently cover or ensure IK and developments of indigenous peoples (Mugabe 1999). The World Intellectual Property Organization (WIPO), one of the institutions that deal with intellectual property, has just started to address these sensitive issues (Vasilev et al. 2020).

\section{Methodology}

In addition to desk-based research, data were collected qualitatively using semi-structured informal interviews and knowledge holders' experiences in two rural villages in Vhembe district, the Limpopo province of South Africa. The sampling of the study participants was both convenient and purposive. Firstly, the authors' familiarity with the study area, knowledge holders and previous study contacts simplified the data collection process. Secondly, knowledge holders were selected on the ground of their willingness to participate in the study, and all indigenous protocols of data collection and writing were meticulously followed (Cresswell \& Plano Clark 2011). Key participants included traditional healthcare practitioners, elderly people (those above 60 years of age), African Studies lecturers and youth (those between the ages of 14 and 35 years). Informal focus group interview participants were sampled through a convenient sampling technique. With a convenient sampling technique, participants were involved in the study merely because they happened to be where the authors were collecting data (Etikan, Musa \& Alkassim 2016). The majority of knowledge holders and participants have historically associated UNIVEN African Studies scholars and similar researchers as advocates for the development and this has effectively enhanced cooperation in data collection processes.

\section{Findings}

The study findings are presented in three themes.

\section{The collection, preservation and dissemination of indigenous knowledge systems}

The collection, preservation and dissemination of IKS were generally observed by participants to be performed in line with Sankofaism. Sankofaism is a philosophical paradigm that focuses on promoting African and indigenous ways of knowledge and skill development (Dei 2012). The African concept of Sankofa emphasises building bridges between the past and present to offer a formidable future. It provides a renaissance launch pad for the preservation of a treasured positive past, which seeks to provide the foundations that promote methodologies that are consistent with realities in Africa (Eshun 2011). It is a pivotal theme in Afrocentric education, philosophy and cultural milieus as it presents platforms for confronting mischaracterisations of African creative and pedagogical spaces (Bastos 2009).

In line with this, Khalala, Botha and Makitla (2016) stipulated that:

The National Recordal System initiative is undertaken by the Department of Science and Innovation to enable communities, guilds, and other holders of Indigenous Knowledge to record their knowledge holdings for future economic benefit and social good. It is envisioned to be the leading IKS treasure hub through the recording, storing, management, maintenance, dissemination, and protection of IK for communal socio-economic development in South Africa. The NRS is supported by National Indigenous Knowledge Management Systems which will comprise a semantic Digital Library with custom-developed metadata schemata and a sophisticated security model to protect, preserve Indigenous Knowledge, an advanced semantic search engine, a sophisticated catalogue system, and an overarching integration 
architecture that combines the subsystems into a coherent, fit for the purpose system. (pp. 10-11)

Participants were clear that the methodological process that should be followed in the collection, preservation and dissemination of IKS ought to be in line with the indigenous protocols of that community. Failure to follow that was observed to undermine the knowledge and the holders of such knowledge, thus likely to hinder its acceptance when digitised.

\section{Indigenous ways contributed to indigenous knowledge systems being threatened with extinction}

The big challenge confronting African communities is the formation of cultural intergenerational strategies to preserve, manage and share IK. This section, therefore, evaluated the efficacy of African ways of transmitting knowledge from one generation to the other. Besides this, other factors that destabilised knowledge management of African IK are colonial and postcolonial education. These two have been labelled by Whatman and Duncan (2005:120) as vital instruments that excluded positive teaching and learning of IK and maliciously labelled IK as evil and archaic. The latter is still peddled by Pentecostal churches who maintain that it is demonic. The study participants observed that features that have resulted in the loss and extinction of IK are 'institutional, structural and personal'. Most academic staff and some knowledge holders concurred that indigenous peoples' ways of preserving, managing and sharing knowledge have expressively catapulted to the erosion of this unique knowledge in the Vhembe district.

According to participants, some indigenous ways of preserving, managing and sharing IK included the use of songs, dances, games, initiation schools, storytelling, taboos and superstitions and others. One elderly observed the following regarding the usage of traditional games:

'During mahundwane indigenous knowledge was preserved, managed, and shared. Mahundwane was a game that was designed for the community children so that they be taught the norms and values of the VhaVenda people. This game was mainly and exclusively for children to learn the family setup and lifestyle management of households in the absence of parents. Elderly boys and girls who would have attended 'initiation schools' (for girls - vhusha and boys - vhutamba vhutuka) were the ones who would be in charge of the small ones to instill discipline and arrange how events unfold.' (Participant C, 2019, Vhembe District)

Traditional health practitioners noticed that some IK was merely passed to certain groups of people and not everyone, underpinned to secrecy. Some of these ways were regarded as sacred as they involved the interference of the ancestors in governing its management. The youth participants were frank and outspoken that some of these practices are out of touch with time and need to be modernised as they no longer live in the past. Information that is orally transmitted is easily forgotten and subject to discrepancy each time it is passed as some aspects in the information are diminished and lost. They indicated that in each generation some things changed thereby resulting in some IK being lost. Some of these ways were argued by some parents as violating human rights, thus they were now discouraging their kids from attending. For example, Mdhluli and Kugara (2017) reports deaths of initiates that were cited as a stumbling block and that the responsible officials were dragging their feet to do away with bogus practitioners operating the 'fly by night schools'. In contrast to that, the senior citizens, although in minority, opined that the rise of misdemeanour amongst the youth created an environment that was not safe for children; hence the traditional ways of passing information for management was disrupted.

In contrast, in other societies, traditional practitioners and elderly participants observed that IK was reported to be fast phasing out, yet with serious social consequences. These participants confidently noticed that the fading away of IKS has and continues to manifest itself in numerous forms that include the rise in heinous crime rates, unemployment, mysterious missing and deaths of persons, misfortunes and diseases, moral decadence, climate change, ecosystem or environmental degradation, miscarriages and extinction of some wildlife. Even though this sparked debates with some who seemed to say they could explain the events, this group maintained that it has much to do with spirituality than what many people say. To add, it was noticed that the death of some knowledge holders and taking their knowledge to the grave without it being passed on has been a challenge with indigenous ways of preserving, managing and sharing knowledge.

Throughout history, IKS were often labelled and dismissed as archaic and 'primitive' because of the slow pace of IKS ways to conform to change. This has been mainly because of the reasons that IKS have been birthed through traditions that developed in the course of 'trial and error' and confirmed to be flexible to acclimatise with time and change (Melchias 2001:15). Even though some youth indicated some change that some come up in the music sector (incorporating indigenous values and norms), some of this 'hybrid music' was criticised by elderly participants that they are missing the point in transmitting IK as it focused on petty issues of the current youth. To clarify and shed light on the given view of Melchias, the authors beg to differ from that submission and point out that IKS were also developed by experimentations although these experiments were not documented, and the knowledge systems were legitimised and fortified under suitable institutional frameworks, culture and practices. They have been passed on to other generations (although discriminatorily) and have enabled indigenous people to survive, manage their natural resources and govern themselves.

Moreover, other participants were of the view that IKS was being examined and mercilessly judged out of context. However, these participants opined that it was a genuine and objective assessment as it sought to upgrade its ways of knowledge banking. In light of this, Lambrecht (2000) argued 
that the distinction between IKS and the Western knowledge system (WKS) assumes that knowledge is fixed in time, space and content whereas the creation of knowledge is a fluid process that evolves in terms of political, institutional, cultural and economic changes. The authors maintain that IKS and WKS are not fixed. Davis (2000) added that the distinction has the effect of creating hierarchies of knowledge thereby placing the so-called WKS in a dominant position and the IKS in a subordinated position. As a result, the majority of the participants agreed that to some extent IK has ceased to play its traditional role as a moral compass in the preservation, management and sharing of IK amongst indigenous livelihoods. The youth and most participants who were interviewed clamoured and advocated for modern methods that incorporate and mix African IK and scientific technology as it is more appealing to them for knowledge management.

\section{Digital library}

Indigenous knowledge has been observed to be fading away slowly in the Vhembe district and is at risk of becoming extinct. However, the authors are of the humble view that if appropriate strategies are not adopted, sooner or later this knowledge will become a history, hence the need for a digital library. The youth noticed that the advent of a digital library in preserving, managing and sharing Vhavenda IK is a way to go to restore the cultural heritage that is unknown to them. Moreover, this was labelled by the youth as an appropriate measure that has the potential of breeding new 'opportunities for development agencies, businesses, nongovernmental organisations (NGOs), and information agencies, including schools and libraries, to partner with rural communities, national governments and social entrepreneurs to create, manage and preserve knowledge and skills that are unique to communities in Limpopo. The youth were happy about this as they noticed that this has already been deemed to take place as some information centres are known for posting audio feeds and/or videos of IK to social media and communication technologies available in and around the Vhembe district. For example, Dr Rannditseni (PhD African Studies graduate) and Dr Ramavhunga (PhD African Studies graduate) have been aired out live on the Limpopo local radio engaging the members of the public with the IK they have studied. In addition, Ms Madima ( $\mathrm{PhD}$ candidate, University of Venda - African Studies) is in the process of digitising Vhavenda indigenous games targeting the youth. It is the authors' submission that having a learned knowledge holder from the community to provide such information to the communities would illustrate the value of digital knowledge. The learned participants applauded the digital libraries as having the potency to brood an environment that permits indigenous peoples to engage and allow the osmosis of ideas about agriculture, medical care and soil conservation.

From the participants' views, an introduction and intensive expansion of social media technologies in introducing IK as a way of luring the youth to learn is a viable and foundational way of preserving, managing and sharing IK. It was unveiled in the study that there is no doubt that numerous young people are inclined to social media, thus introducing the digital library in the dissemination of IK would be a success. Moreover, these digitalised library activities should focus on the production and dissemination of standardised IK through television, telephone, Facebook, WhatsApp, radio and billboard advertisements. These digitalised IK data should appear directly to the general public, and they are expected to be fairly appropriate and particularly effective as many people today spend a great deal of their time on such media. Lor (2004) opined that 'libraries can assist with the discovery and recording of knowledge, organise it for use and promote its appreciation, including respect for the communities that produced it'. The latter submission of Lor fanned a bone of contention and forms the concept of this article and is discussed next.

The whole idea of digitalising Vhavenda IK as a way of preserving, managing and sharing for intergenerational sustenance of this unique knowledge was received with mixed feelings from other participants. Various views that seemed sensitive were captured from participants as they cautioned how and by who this should be performed. This resulted in the authors exploring the challenges and fears of knowledge holders and other participants with the idea of digitalising IK for future generations.

\section{Challenges and fears of documenting indigenous knowledge systems}

Most traditional healthcare practitioners and elderly people were passionately angered with digitalising IK for future generations as they indicated that it was going to be aired out for public consumption. They were not advocating for it as they observed that this issue had a bearing on the copyright and IPR issues that are included in the United Nations Declaration on Rights of Indigenous Peoples (United Nations Permanent Forum on Indigenous Issues 2007). Some participants suspected that the digitalising project was a western-driven project that wishes to use Vhavenda knowledge holders as tools to benefit financially from their indigenous knowledge, without sharing any benefits with the Vhavenda knowledge holders.

Participants indicated the collective nature of IK and the danger of it being shared with outsiders at the expense of an individual. In cases of intellectual property, the Economic Commission for Africa recommended that 'oral tradition and IK in African communities should be exploited in all their forms of expression, giving cognisance to the protection of intellectual property rights' (United Nations 2001:3). However, the main challenge that is a drawback in the quest to protect IK is that copyright is Eurocentric, 'placing emphasis on individuality and material', contrary to African indigenous cultural norms and knowledge (Greyling \& McNulty 2011). Kuruk (2002) added that the 'historic collectivist approach to ownership of creative expressions associated with oral tradition is conceptually different from the Western copyright system, which ascribes ownership to individuals'. 
Some elderly participants and the youth noticed that most library service points are located in urban areas, excluding the immense majority of the rural communities. Because the library services are geographically isolated from rural communities, it creates barriers and invisible forces that prevent rural communities from accessing library services and resources. Even wherein these library services and resources are brought to these communities, the poor infrastructure of many African libraries cannot afford the cost of digital libraries in preserving, managing and sharing IK. Besides costs, it will take a long for them to be trained to use and understand digital technology (Owiny, Mehta \& Maretzki 2014).

Some participants indicated that digitalising IK would predictably result in misinformation of this unique knowledge. Mawere (2011) observed that there is a general adage that notes that 'lies, when documented, resemble truths'. Having this risk at hand, digitalising IK has been opined by elderly participants to have a high tendency of being used maliciously into cooked eye-catching inscriptions, catchy rhetorical practices and exaggerated achievements as a way of luring and winning the hearts of their targeted audiences. In that regard, Norris (1980) succinctly denounced the immorality of misinformation by opining that:

[T]he advertiser should always tell the whole truth about the product he wants to sell and should judge the message not by what it says but by what the reader is most likely to think it says. (p. 7)

The digitalising of IK thus, should not manipulate, misinform or influence the prospective consumer deliberately or otherwise. Moreover, the elderly participants and traditional health care practitioners observed diversities regarding the practices should always be observed to avoid misrepresentation. This led to a discussion on how the Xhosa culture had been 'misrepresented' in a movie in South Africa and ongoing consultations with relevant stakeholders were said to be ongoing. Some Facebook comments that followed this thorny issue were as follows:

Comment 1: 'If the Xhosas feel they were wrongly depicted in this film, they have aright to protest'. (sic)

Comment 2: 'From an anthropological perspective, Xhosa cultural ideologies and traditions are particularly fluid and vary considerably from region to region. Also, much of it remains unrecorded (it is shared/passed on orally) so there will naturally be discrepancies. So unfortunately, it doesn't really matter how careful filmmakers were about cultural accuracy, the data will always be incorrect to at least one group or another. This scenario is a common filmmaker's trap'. (sic)

Comment 3: 'Mxm...it's a movie people...do you boycott action movies because of fake bullets and explosions...This is not a documentary but a movie surely we expect some sugar and spices in it'. (sic)

Because the digitalising of IK will not be for movies but for preservation, managing and sharing of IK, significant attention has to be devoted to examining the ethical problems associated with the digitalisation process. This is because some digital advertisement in South Africa has been characterised by the moral wrong of exaggerated competence.

The participants were also at pains trying to address whether digitalising of this knowledge would be possible because of the 'holistic' nature of IK. Some participants indicated that it would lose its intrinsic value as soon as it is removed from the community in which it is embedded and digitalised. Mawere (2010) alluded that:

The fallacy of science is its inability to provide scientific explanations to issues of a metaphysical nature and to present alternative convincing explanations outside the canonical frameworks of scientific inquiry. (p. 13)

So, whilst digitalisation strove to give convincing means of preserving, managing and sharing IK, it falls short in capturing and disseminating the unadulterated metaphysical aspect of IK. This aspect cannot be adequately answered without challenging the monopoly of science in trying to adopt it as a way of preserving, managing and sharing IK.

\section{Conclusion}

There is a unanimous growing consensus that IK is indispensable for the day-to-day running of indigenous peoples for development, governance and health. However, this unique knowledge is in danger of disappearing and becoming extinct if proper intergenerational measures are not taken to preserve, manage and share it. As such, to curb the fading away of IK a digital library is advocated for. In this article, the authors have explored the possibilities and efficacy of preserving, managing and sharing IK via digital libraries for the benefit of future generations. However, to smoothly achieve this, ethical problems associated with digitalisation process need to be meticulously observed.

\section{Acknowledgements}

We would like to thank the Lord Almighty God for giving us life, strength, good health and sound mind throughout the period of writing the article. Our sincere appreciations are directed to the following people who played a direct role in this article: my co-authors, Prof. Mokgoatšana, MR Vuma Lucky and my 'Emperor' - my husband Dr (Adv) Stewart Lee Kugara - Postdoctoral fellow in the Department of Culture and Political Studies, you have been a guiding light in the writing of this article. We also wish to acknowledge the guidance and support of the University of Limpopo. We pray that the Lord keep you healthy so that you have strength and that we write more articles. My father Lucas Mdhluli and mother Jenesy Mdhluli, 'Onga', and my adorable child Makanaka Rixile Lee Kugara - you were all my beacons of support and encouragement.

\section{Competing interests}

The authors declare that they have no financial or personal relationships that may have inappropriately influenced them in writing this article. 


\section{Authors' contributions}

The authors contributed equally to the writing of this article.

\section{Ethical considerations}

University of Venda, Research Ethical Clearance Committee SHSS/19/AS/01/1503

\section{Funding information}

This research received no specific grant from any funding agency in the public, commercial or not-for-profit sectors.

\section{Data availability}

This research received no specific grant from any funding agency in the public, commercial or not-for-profit sectors.

\section{Disclaimer}

The views and opinions expressed in this article are those of the authors and do not necessarily reflect the official policy or position of any affiliated agency of the authors.

\section{References}

Bastos, F.M.C., 2009, 'Art education in the spirit of Sankofa', Art Education 62(2), 5-15. https://doi.org/10.1080/00043125.2009.11519005

Blacking, J., 1967, Venda children's songs: A study in ethnomusicological analysis, Witwatersrand University Press, Johannesburg.

Chambers, R., 1991, Rural Development: Putting the last first, John Wiley \& Sons, New York, NY, pp. 47-53.

Cresswell, J.W. \& Plano Clark, V.L., 2011, Designing and conducting mixed method research, 2nd edn., Sage, Thousand Oaks, CA, pp. 78-94.

Davenport, T.H., 1998, Some principles of knowledge management, viewed 12 March 2018, from https://www.strategy-business.com/article/8776.

Davis, A., 2000, 'Witch purging in the Northern Province of South Africa: A victim profile and assessment of initiative to deal with witchcraft', unpublished paper, Witchcraft Summit, Giyani, 28th September.

Dei, G.S., 2012, 'Indigenous anti-colonial knowledge as "heritage knowledge" fo promoting Black/African education in diasporic contexts', Decolonization: Indigeneity, Education \& Society 1(1), 102-119.

Eshun, G., 2011, Ecotourism development in Ghana: A postcolonial study with a focus on Boabeng-Fiema Monkey Sanctuary and Kakum National Park, University of Leicester, Leicester.

Etikan, I., Musa, S.A. \& Alkassim, R.S., 2016, 'Comparison of convenience sampling and purposive sampling', American Journal of Theoretical and Applied Statistics 5(1), 1-4. https://doi.org/10.11648/j.ajtas.20160501.11

Greyling, E. \& McNulty, N., 2011, How to build an indigenous digital library through community participation: The case of the Ulwazi Programme, viewed 18 February 2019, from https://www.niallmcnulty.com/wp-content/uploads/2019/09/How to build_an_Indigenous_Digital_Libra.pdf.

Human Rights and Equal Opportunity Commission, 2009, Native Title Report, 2008 Chapter 7. The protection of indigenous knowledge, pp. 211-228, Australian Human Rights Commission, Sydney, viewed 18 February 2019, from https:// humanrights.gov.au/sites/default/files/content/social justice/nt report/ humanrights.gov.au/sites/d
ntreport08/pdf/chap7.pdf.

Kaniki, M.A. \& Mphahlele, K.M.E., 2002, 'Indigenous knowledge for the benefit of all: Can knowledge management principles be used effectively?', SA Journal of Library and Information Science 68(1), 1-15. https://doi.org/10.7553/68-1-753

Khalala, G., Botha, A. \& Makitla, I., 2016, 'The process as an element of UX in collecting indigenous knowledge: A case study in South Africa', in 2016 IST-Africa Week Conference, pp. 1-12, IEEE, Durban.

Kugara, S.L., 2017, 'Witchcraft belief and criminal responsibility: A case study of selected areas in South Africa and Zimbabwe', Doctoral dissertation, University of Venda.

Kugara, S.L., Matshidze, P.E., Netshandama, V.O., Mdhluli, T.D. \& Makhanikhe, T.J. 2020 a, Exploring IKS and WKS worldviews to foster and advance knowledge in the 21 st Century. Africa rising? Navigating the nexus between rhetoric and emerging reality, pp. 221-238, Universidad de Navarra, Pamplona.
Kugara, S.L., Mdhluli, T.D., Daswa, T.J., Matshidze, P.E. \& Ramavhunga, N.E., 2020b, 'The significance of multicultural methodologies on African indigenous knowledge research', in Ethical Research Approaches to Indigenous Knowledge Education, pp. research, in Ethical Research Approaches to Indigenous Knowledge Education, pp. book/ethical-research-approaches-indigenous-knowledge/231907.

Kuruk, P., 2002, 'African customary law and the protection of folklore', Copyright Bulletin 36(2), 4-32, viewed 18 February 2019, from http://unesdoc.unesco.org/ images/0012/001277/127784e.pdf.

Lambrecht, I., 2000, 'Cultural artefacts and the oracular trance states of the Sangoma in South Africa', African Art and Rituals of Divination, Metropolitan Museum of Art, New York, NY.

Lanzano, C., 2013, 'Kind of knowledge is "indigenous knowledge"? Critical insights from a case study in Burkina Faso', Transcience 4(2), 1-16.

Lor, P.J., 2004, 'Storehouses of knowledge? The role of libraries in preserving and promoting indigenous knowledge', Indilinga: African Journal of Indigenous Knowledge Systems 3(1), 45-56.

Mabawonku, I.M., 2002, 'The systematic management of indigenous knowledge: A review of oral information projects in a library school', in SCECSAL 2002: From Africa to the world-the globalization of indigenous knowledge systems, pp. 49-60, LIASA, Pretoria.

Mawere, M., 2010, Reconstructing African philosophy: African metaphysical epistemology, Lambert Academic Publishers, s.l.

Mawere, M., 2011, 'Ethical quandaries in spiritual healing and herbal medicine: A critical analysis of the morality of traditional medicine advertising in southern African urban societies', Pan Africa Medical Journal 10, 1-10. https://doi. org/10.4314/pamj.v10i0.72212

Mbiti, J.S., 1969, African religions and philosophy, Praeger, New York, NY.

Mdhluli, T.D. \& Kugara, S.L., 2017, 'Probing virginity testing on girl child: The case of KwaZulu-Natal, South Africa', Gender and Behaviour 15(2), 9250-9259.

Melchias, G., 2001, Biodiversity and conservation, Science Publishers, Inc., Enfield.

Mugabe, J., 1999, Intellectual property protection and traditional knowledge, African Centre for Technology Studies, Nairobi, p. 37.

Mumba, N., 2002, 'Metamorphosis or mutation: Managing information in a changing world', in SCECSAL 2002: From Africa to the world-the globalization of indigenous knowledge systems, pp. 311-321, LIASA, Pretoria.

Muswazi, P., 2001, 'Indigenous knowledge management in Swaziland: Perspectives', Information Development 17(4), 250-255. https://doi.org/10.1177/ 0266666014241079

$\mathrm{Ng}$ 'etich, K., 2005, Indigenous knowledge, alternative medicine, and intellectual property rights concerns in Kenya, viewed 12 March 2018, from https://www. iprsonline.org/Links/conferences/general_assembly11/papers/ngetich.pdf.

Nonaka, I. \& Toyama, R., 2005, 'The theory of the knowledge-creating firm: Subjectivity, objectivity, and synthesis', Industrial and Corporate Change 14(3), 419-436. https://doi.org/10.1093/icc/dth058

Norris, V.P., 1980, 'Advertising history according to the textbooks', Journal of Advertising 9(3), 3-11.

Owiny, S.A., Mehta, K. \& Maretzki, A.N., 2014, 'The use of social media technologies to create, preserve, and disseminate indigenous knowledge and skills to communities in East Africa', International Journal of Communication 8, 14.

Semali, L.M. \& Kincheloe, J.L., 1999, 'Introduction: What is indigenous knowledge and why should we study it?', What is indigenous knowledge?, pp. 3-57, Falmer Press, New York, NY.

Smith, J.G. \& Lumba, P.M., 2008, 'Knowledge management practices and challenges in international networked NGO's: The case of One World International', The Electronic Journal of Knowledge Management 6(2), 167-176.

Stayt, H.A., 1931, The Bavenda, Oxford University Press, London.

Swanepoel, A., 2005, 'Lessons learned from library mergers at colleges of higher education in Flanders', South African Journal of Library and Information Science 71(1), 85-92. https://doi.org/10.7553/71-1-659

Syed-lkhsan, S. \& Rowland, F., 2004, 'Knowledge management in public organizations: A study on the relationship between organizational elements and the performance of knowledge transfer', Journal of Knowledge Management 8(2), 95-111. https:// doi.org/10.1108/13673270410529145

Vasilev, V.L., Gapsalamov, A.R., Akhmetshin, E.M., Bochkareva, T.N., Yumashev, A.V. \& Anisimova, T.I., 2020, 'Digitalization peculiarities of organizations: A case study', Entrepreneurship and Sustainability Issues 7(4), 3173. https://doi.org/10.9770/ jesi.2020.7.4(39)

United Nations, 2001, Draft Declaration on the rights of indigenous peoples, viewed 12 March 2018, from http://www.gcc.ca/Political_Issues/international/.

United Nations Permanent Forum on Indigenous Issues, 2007, Declaration on the rights of indigenous peoples, viewed 21 February 2019, from https://www.un. org/esa/socdev/unpfii/documents/faq_drips_en.pdf.

Whatman, S. \& Duncan, P., 2005, 'Community participation in Indigenous education: Learning from the past, in policy and practice', in J. Phillips \& J. Lampert (eds.) Introductory indigenous studies in education: The importance of knowing, pp. 117-138, Pearson Education Australia, Sydney.

World Bank, 2002, Indigenous knowledge and intellectual property rights, viewed 12 March 2018, form http://www-wds.worldbank.org/servlet/WDSContentServer/ WDSP/IB/2002/01/25/000094046_02011504020266/Rendered/PDF/ multiopage.pdf. 